\title{
Article \\ Heterogeneous Photo-Fenton Reaction for Olive Mill Wastewater Treatment-Case of Reusable Catalyst
}

\author{
Cristina Agabo-García 1,2 (D), Naima Calderón ${ }^{2}$ and Gassan Hodaifa ${ }^{2, *(D)}$ \\ 1 Chemical Engineering and Food Technology Department, Faculty of Science, University of Cádiz, \\ ES-11510 Puerto Real, Spain; cristina.agabo@uca.es \\ 2 Molecular Biology and Biochemical Engineering Department, Chemical Engineering Area, \\ Faculty of Experimental Sciences, University of Pablo de Olavide, ES-41013 Seville, Spain; \\ naimacalderonf@gmail.com \\ * Correspondence: ghodaifa@upo.es; Tel.: +34-954-978-206
}

check for updates

Citation: Agabo-García, C.; Calderón, N.; Hodaifa, G. Heterogeneous Photo-Fenton Reaction for Olive Mill Wastewater Treatment-Case of Reusable Catalyst. Catalysts 2021, 11, 557 https://doi.org/10.3390/ catal11050557

Academic Editor: Narmina O. Balayeva

Received: 6 April 2021

Accepted: 27 April 2021

Published: 27 April 2021

Publisher's Note: MDPI stays neutral with regard to jurisdictional claims in published maps and institutional affiliations.

Copyright: (c) 2021 by the authors. Licensee MDPI, Basel, Switzerland. This article is an open access article distributed under the terms and conditions of the Creative Commons Attribution (CC BY) license (https:// creativecommons.org/licenses/by/ $4.0 /)$.

\begin{abstract}
Heterogeneous catalysts can be an efficient and economical option for olive mill wastewater (OMW) treatment by an advanced oxidation process if they could be reused. In this work, OMW was treated using a heterogeneous photo-Fenton reaction (artificial ultraviolet light $/ \mathrm{H}_{2} \mathrm{O}_{2} / \mathrm{HFeO}_{2}$ ). For this purpose, different concentrations of $\mathrm{HFeO}_{2}$ were tested: $0.04 ; 0.3 ; 0.8 ; 5.0 ; 10.0 ; 20.0 ; 30.0$, and $50.0 \mathrm{~g} / \mathrm{L}$. The following operational conditions were chosen: $\mathrm{pH}=3.0$, temperature $=20^{\circ} \mathrm{C}$, agitation rate $=700 \mathrm{rpm}$. The experimental results showed high removal percentages of the main OMW characterization parameters at $50 \mathrm{~g} / \mathrm{L}$ of $\mathrm{HFeO}_{2}: \% \mathrm{COD}_{\text {removal }}=62.8 \%$; \%total phenolic compounds $(\mathrm{TPCs})=88.9 \%$. These results were also compared with those of other control oxidation systems, i.e., $\mathrm{UV}, \mathrm{H}_{2} \mathrm{O}_{2}$, and $\mathrm{UV} / \mathrm{H}_{2} \mathrm{O}_{2}$, which provided 35.5 and $56.1 \%$; 46.2 and $74.0 \%$; 48.0 and $76.8 \%$ removal, respectively. In addition, the catalyst was reused three times, recovering more than $90.5 \%$ of it.
\end{abstract}

Keywords: olive mill wastewater; photo-fenton reaction; artificial UV light; heterogeneous reaction; catalyst recycling

\section{Introduction}

Olive oil is produced in olive mills either by the discontinuous method (press) or by the continuous centrifugation method. The continuous centrifugation methods may involve a decanter with three exits (olive oil, pomace, and wastewater) or a decanter with two exits (olive oil and pomace). There are about 25,000 olive mills worldwide. Wastewater arising from olive processing is one of the strongest industrial effluents. In this sense, for press and three-exit continuous centrifugation processes, the $\mathrm{COD}$ and $\mathrm{BOD}_{5}$ values of wastewater are equal to 40-220 $\mathrm{g} \mathrm{O}_{2} / \mathrm{L}$ and 35-110 $\mathrm{g} \mathrm{O}_{2} / \mathrm{L}$, respectively [1-4]. However, for the two-exit continuous centrifugation process, the $\mathrm{COD}$ and $\mathrm{BOD}_{5}$ values of wastewater are equal to 0.5-65 $\mathrm{g} \mathrm{O}_{2} / \mathrm{L}$ and 8.5-19 $\mathrm{g} \mathrm{O}_{2} / \mathrm{L}$, respectively [5-7]. These values for the COD and $\mathrm{BOD}_{5}$ parameters are higher than that those registered for wastewaters generated by other food industries, such as potato chips (5940-7058 $\mathrm{mg} \mathrm{O}_{2} / \mathrm{L}$ and 2729-3415 $\mathrm{mg} \mathrm{O}_{2} / \mathrm{L}$ ) and potato starch plants (900-1400 $\mathrm{mg} \mathrm{O}_{2} / \mathrm{L}$ and 1100-1500 $\mathrm{mg} \mathrm{O}_{2} / \mathrm{L}$ ) [8].

The management of OMW consists of its controlled or uncontrolled spreading in soils. This practice has led to severe environmental problems. In fact, the Spanish Government forbid the direct discharge to soils in 1981 and obligate to collect OMW in evaporation reservoirs [1]. This wastewater management method has a few maintenance requirements and is enhanced under Mediterranean conditions. However, this method has some drawbacks such as the need of large areas to collect the large amounts of OMW generated, bad odors due to the evaporation of volatile organic acids such as butyric, acetic, or propionic acids and insect plagues, fermentation processes with the subsequent emission of greenhouse gasses such as $\mathrm{CH}_{4}$ or $\mathrm{H}_{2} \mathrm{~S}$. Besides, OMW (acidic $\mathrm{pH}$ and organic content) persists and, by 
floods and infiltrations, may lead to higher problems such as contamination of aquifers, soils, and the air $[2,9]$.

To perceive the magnitude of the OMW problem, a medium-sized olive mill (the most widespread type of mills) generates between 10 and $15 \mathrm{~m}^{3}$ of OMW per day and, during the olive harvesting period (November-February), the OMW volume production is higher. As a consequence of this environmental situation, new research is focusing on different low-cost OMW treatments with the aim to regenerate OMW and recycle them in the proper process of olive oil production or for irrigation purposes [6]. In this sense, different conventional (such as aerobic/anaerobic digestion treatments, composting, or co-digestion) and non-conventional (such as filtration, flocculation, advanced process technologies, or membrane technologies) technologies have been proposed alone or in combination to regenerate OMW [10].

Aerobic treatments are commonly used when the organic load is not very high such as in the case of olive washing wastewater [11]. On the other hand, in the case of anaerobic digestion, in spite of producing a high-value product (biogas), the high organic load is not completely eliminated [12], and a dilution step is desirable for reducing the toxicity of some compounds (i.e., phenolic compounds) on microorganisms' growth. The composting technic has been also checked for OMW treatment [13] in order to generate another highvalues products (fertilizers). However, this operation requires a long period of time (several weeks) for a complete composting and the subsequent evaluation of the resulting products, especially from the point of view of their phytotoxicity.

Physical simple treatments such as dilution, evaporation, centrifugation, or sedimentation have a great potential for the decontamination of OMW but are usually integrated in a complete process. As an example, assisted sedimentation (by flocculation) has been studied using common chemical agents such as ferric chloride, aluminum chloride, ferrous sulphate, among others [1]. On the other hand, the membrane technology has been deeply investigated in OMW treatment. However, the high organic load in OMW prevents this technology from working efficiently; moreover, it presents several disadvantages such as (i) the fractionation of OMW, generating solid waste that requires further treatment, (ii) separation phases in concentrate and permeate but not organic matter degradation, (iii) continuous membrane fouling, (iv) short life shift of the membrane, and (v) high costs [14].

In the last years, advanced oxidation processes (AOPs) have emerged as a promising technology due to the simplicity of the techniques and the high organic removal efficiencies obtained. Especially, different authors have highlighted the benefits of using this technology for OMW [15-17] instead of the conventional biological treatment. Different AOPs have been used for OMW treatment during the last years including photolysis, photo-oxidation, Fenton's, and photo-Fenton reaction. Photo-Fenton-like oxidation and ozonation are used alone or in combination with UV-light. In this sense, Hodaifa et al. $[17,18]$ obtained $25-35 \%$ conversion of TOC for photolysis and $38-43 \%$ for a UV $/ \mathrm{H}_{2} \mathrm{O}_{2}$ system during the first $30 \mathrm{~min}$. In addition, $57.9 \%$ of TOC conversion was obtained in a photo-Fenton test by using $\mathrm{FeCl}_{3}$ as a catalyst [17] and $47.6 \%$ of TOC conversion during a photo-Fenton-like oxidation using $\mathrm{TiO}_{2}$ as a catalyst [18], with a catalyst concentration of $3 \mathrm{~g} / \mathrm{L}$ and an operation time of $5 \mathrm{~min}$, respectively. Ozonation has been applied to OMW alone and in combination with UV light [19] and in the presence of different catalysts such as $\mathrm{BiFeO}_{3}$ [20], obtaining a maximum COD conversion of $98 \%$ for $\mathrm{O}_{3} / \mathrm{BiFeO}_{3} / \mathrm{S}_{2} \mathrm{O}_{82}$ during $40 \mathrm{~min}$.

These methods are based on the use of strong oxidant agents such as ozone, hydrogen peroxide, sodium hypochlorite, potassium permanganate [2], which oxide a wide range of compounds, irrespective of their chemical structures, including recalcitrant compounds, without the generation of secondary pollutants. These oxidants generate hydroxyl radicals $\left(\mathrm{OH}^{\bullet}\right)$, which are highly reactive and unstable species that transform complex organic structures into final simple inorganic compounds such as $\mathrm{CO}_{2}$ and $\mathrm{H}_{2} \mathrm{O}[21,22]$. The oxidants can be used in combination with other enhancers of the reaction such as a source of energy (UV lamps, solar light) or catalysts [23]. Having high efficiency for organic matter elimination, AOPs also involve simple processes and mild operational conditions [22]. 
However, the main challenges are the costs of the process (especially, the chemicals costs) and the recovery of the catalyst during and after treatment. Hence, it is suggested to use this technology as the main process, integrating it with other physicochemical pretreatments in order to reduce the initial organic load before proceeding with the AOP step (for catalyst cost reduction). In addition to include a post-physical treatment method in order to eliminate the residual catalyst [24,25]. In this sense, Benitez et al. [19] studied the combination of ozonation and aerobic treatment for OMW treatment obtaining a total conversion of TOC of $84.6 \%$. On the other hand, in previous studies by our group, OMW was treated by a combination of photo-Fenton and sedimentation operations, obtaining a total conversion of TOC of $96.1 \%$ [23]. Another option to reduce costs would be using a catalyst that can be reused to avoid the continuous removal of the catalyst. In this sense, solid catalysts have emerged as promising reusable catalysts due to their easy separation from wastewater, avoiding secondary pollution with metallic ions, as it happens in liquid catalysts [26].

In a heterogeneous photo-Fenton-like reaction, $\mathrm{UV}$ activates the catalyst to react with $\mathrm{H}_{2} \mathrm{O}_{2}$, generating hydroxyl radicals $\left(\mathrm{OH}^{\bullet}\right)$. The heterogeneous catalyst is usually based on micro- or nanoparticles and/or other organic frameworks to have a large specific surface area enhancing the adsorption of reactants and improving the degradation efficiency of organic pollutants [27]. They are based on different components such as iron metals [28], titanium [27], cesium [29], or non-metal catalysts such as sulphate or N-and S-co-doped biomass carbon, activated carbon, graphene oxide, or sulphate [30]. Among the different heterogeneous catalysts, metal catalysts exhibit high activity in AOPs, owing to their excellent electron transfer capability. Specifically, iron-based materials have been successfully used for the photo-Fenton treatment of different compounds. Luo et al. [31] reviewed the different iron-based heterogeneous catalysts. $\mathrm{HFeO}_{2}$ has not been previously evaluated as a catalyst for organic load degradation in wastewater. In this work, $\mathrm{HFeO}_{2}$ was proposed and tested as an efficient catalyst in OMW treatment by a photo-Fenton like reaction. In addition, the catalyst was recovered several times, and its efficiency after reuse was checked and determined.

\section{Results and Discussions}

\subsection{OMW Characterization}

The raw wastewaters used in this work were directly collected from olive mills in Seville province (Spain), which operated with a continuous two-outlet decanter process. Table 1 shows the characterization of the crude mixture $(1: 1 v / v)$ of olive mill wastewaters from olive washing and olive oil washing.

From Table 1, it is clear the high organic load of this kind of wastewater (COD up to $16586 \mathrm{mg} \mathrm{O} 2 / \mathrm{L}$ and total carbon up to $4431.2 \mathrm{mg} / \mathrm{L}$ ) and the non-biodegradable organic matter contained in this $\mathrm{OMW}\left(\mathrm{COD} / \mathrm{BOD}_{5}\right.$ ratio $\left.=8.2\right)$ in comparison to the registered parameters for urban wastewater $\left(\mathrm{COD} / \mathrm{BOD}_{5}\right.$ ratio $\left.=2\right)$, [6].

\section{2. $\mathrm{pH}$ and Conductivity Variations}

Figure $1 \mathrm{a}, \mathrm{b}$ shows the behavior of $\mathrm{pH}$ and electric conductivity for control systems (air, $\mathrm{UV}, \mathrm{H}_{2} \mathrm{O}_{2}$, and $\mathrm{UV} / \mathrm{H}_{2} \mathrm{O}_{2}$ ) and photo-Fenton like reactions at different catalyst concentrations. In general, there was no variation in $\mathrm{pH}$ and electrical conductivity values throughout time. Only a slight increase in $\mathrm{pH}(<0.5)$ appeared in experiments with higher amounts of catalyst, specifically, in those where the concentration of $\mathrm{HFeO}_{2}$ was above $10 \mathrm{~g} / \mathrm{L}$. Because not all reactions taking place during the oxidation time are known exactly, it is possible that some compounds of basic character are produced in the medium due to incomplete degradation of the organic matter (Equation (1)).

$$
\begin{gathered}
\text { Organic matter }+ \text { oxidant } \rightarrow \text { simple products }+\mathrm{CO}_{2}+\mathrm{H}_{2} \mathrm{O} \\
\text { Simple products } \rightarrow \mathrm{CO}_{2}+\mathrm{H}_{2} \mathrm{O}
\end{gathered}
$$


Table 1. Characterization of a mixture of OMW used as the initial sample and the Spanish maximum values allowed for discharge into the public domain (Royal Decree 849/1986).

\begin{tabular}{|c|c|c|}
\hline Parameters & Values & $\begin{array}{l}\text { Spanish Maximum Values Allowed for Discharge } \\
\text { into the Public Domain }\end{array}$ \\
\hline $\mathrm{pH}$ & 4.37 & $5.5-9.5$ \\
\hline Electric conductivity $(\mathrm{mS} / \mathrm{cm})$ & 3.47 & - \\
\hline Turbidity (FTU) & 3453 & - \\
\hline Total solids (\%) & 0.775 & - \\
\hline Total suspended solids (\%) & 0.699 & 30 \\
\hline Organic matter (\%) & 0.571 & - \\
\hline Ashes (\%) & 0.204 & - \\
\hline $\begin{array}{l}\text { Total phenolic compounds } \\
\text { (mg/L) }\end{array}$ & 288 & 1 \\
\hline Fat content (\%) & 0.00360 & 40 \\
\hline Dissolved $\mathrm{O}_{2}(\mathrm{mg} / \mathrm{L})$ & 0.79 & - \\
\hline $\mathrm{BOD}_{5}\left(\mathrm{mg} \mathrm{O}_{2} / \mathrm{L}\right)$ & 2030 & 300 \\
\hline $\mathrm{COD}(\mathrm{mg} \mathrm{O} 2 / \mathrm{L})$ & 16586 & 500 \\
\hline Total carbon $(\mathrm{mg} / \mathrm{L})$ & 4431.2 & - \\
\hline Total organic carbon $(\mathrm{mg} / \mathrm{L})$ & 4252 & - \\
\hline Inorganic carbon $(\mathrm{mg} / \mathrm{L})$ & 179 & - \\
\hline Total nitrogen (mg/L) & 72.8 & - \\
\hline $\operatorname{Iron}(\mathrm{mg} / \mathrm{L})$ & 28.1 & 10 \\
\hline Chlorides (mg/L) & 1132 & - \\
\hline Sulphates (mg/L) & 29 & - \\
\hline $\mathrm{Na}^{+}(\mathrm{mg} / \mathrm{L})$ & 2.73 & - \\
\hline $\mathrm{NH}_{4}{ }^{+}(\mathrm{mg} / \mathrm{L})$ & 2.02 & - \\
\hline $\mathrm{K}^{+}(\mathrm{mg} / \mathrm{L})$ & 195 & - \\
\hline $\mathrm{Ca}^{2+}(\mathrm{mg} / \mathrm{L})$ & 8.00 & - \\
\hline
\end{tabular}

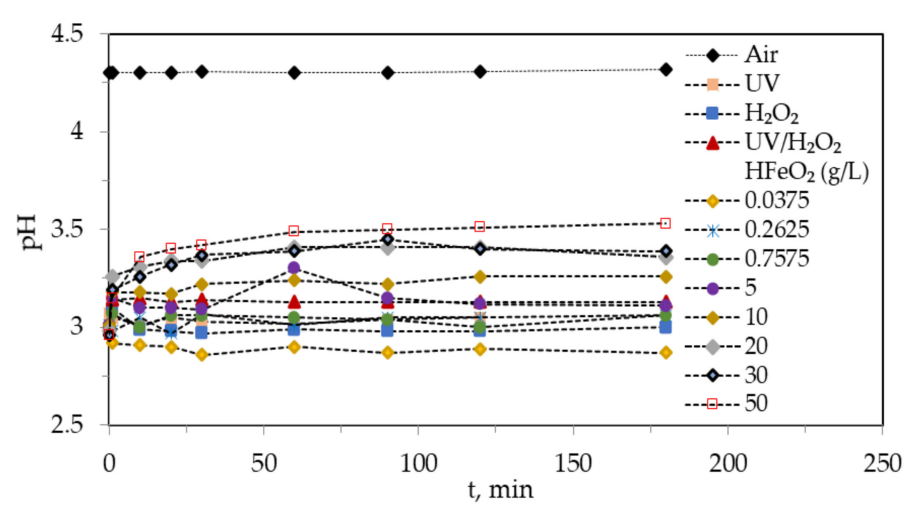

(a)

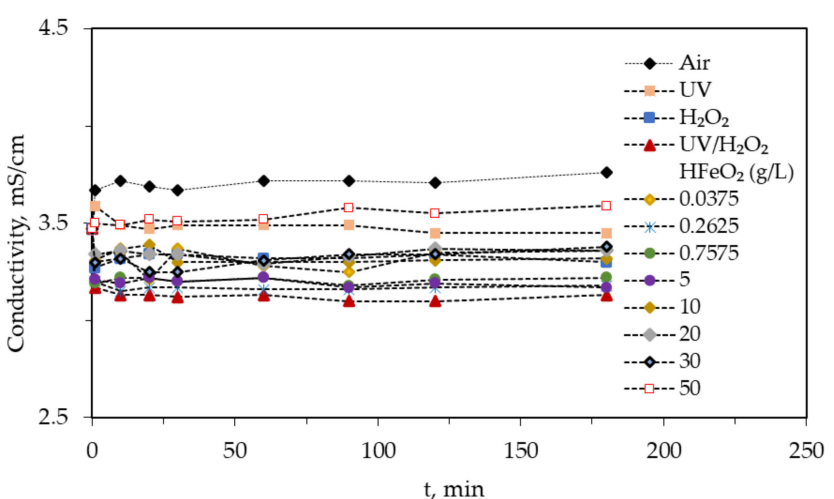

(b)

Figure 1. $\mathrm{pH}(\mathbf{a})$ and conductivity (b) variation throughout of the experiments for different chemical oxidation systems: air, $\mathrm{UV}, \mathrm{H}_{2} \mathrm{O}_{2}, \mathrm{UV} / \mathrm{H}_{2} \mathrm{O}_{2}$, and $\mathrm{UV} /$ catalyst $/ \mathrm{H}_{2} \mathrm{O}_{2}$, with different catalysts doses. Common operating conditions: $\mathrm{COD}_{\text {initial }}=16586 \mathrm{mg} \mathrm{O}_{2} / \mathrm{L}, \mathrm{H}_{2} \mathrm{O}_{2}=35.3 \mathrm{~g} / \mathrm{L}, \mathrm{T}=20^{\circ} \mathrm{C}$, agitation speed $=700 \mathrm{rpm}$, and $\mathrm{pH}=3$.

These behaviors are important to detect two phenomena: (i) the possible transfer of ions from the surface of the catalyst to the medium and (ii) intermediary compounds with basic characteristics during organic matter degradation that could modify the conditions of the reaction.

As for the conductivity recorded (Figure $1 \mathrm{~b}$ ), it can be observed that it remain virtually constant throughout the $3 \mathrm{~h}$ of experimentation and only in the oxidation experiment using $50 \mathrm{~g} / \mathrm{L}$ of $\mathrm{HFeO}_{2}$, we recorded conductivity values higher than those of the experiments with lower catalyst concentrations, which could be due to the catalyst itself or to the partial solubilization of the catalyst surface and the release of iron ions into the medium. However, these conductivity values did not exceed the initial values. The experiment evaluating oxidation by air showed higher conductivity levels than the other experiments, due to the 
lack of $\mathrm{pH}$ modification of the wastewater at the beginning of the experiments as in the other experiments.

\subsection{Organic Matter Degradation}

Figure 2a presents all the chemical oxidation systems referred to the removal percentage of COD during the experiments. The treatments with the lowest efficiencies are clearly air (average \%COD removal $=11.6 \pm 3.54 \%$ ) and UV /light with $35.5 \pm 2.48 \%$. These results are similar to those obtained previously by our research group [23]. In fact, these results highlight the potential of hydrogen peroxide as an oxidant. For this reason, the oxidation systems based on $\mathrm{H}_{2} \mathrm{O}_{2}$ and $\mathrm{UV} / \mathrm{H}_{2} \mathrm{O}_{2}$ showed higher values, i.e., $46.1 \pm 3.03 \%$ and $48.3 \pm 1.53 \%$ of COD removal. On the other hand, when the catalyst was introduced into the oxidation system, the \%COD removal also increased with the augmentation of the catalyst concentration, being optimal $(62.8 \pm 0.454 \%)$ when $50 \mathrm{~g} / \mathrm{L}$ of catalyst was used. The difference in the percentage of elimination with respect to the $\mathrm{H}_{2} \mathrm{O}_{2} / \mathrm{UV}$ system was around $10 \%$; however, it is necessary to consider that the use of a catalyst adds more turbidity to the system, which can interfere with the projection of light from the lamp. In this sense, at a concentration below $1 \mathrm{~g} / \mathrm{L}$ of catalyst, the system showed COD removal around $48.6 \pm 0.859 \%$. Only when the catalyst concentration was $\geq 5 \mathrm{~g} / \mathrm{L}$, the $\% \mathrm{COD}_{\text {removal }}$ was $>50 \%$ (corresponding $X_{\mathrm{TC}}$ and $\mathrm{X}_{\mathrm{TOC}} \approx 0.47$, Figure $2 \mathrm{~b}, \mathrm{c}$ ).

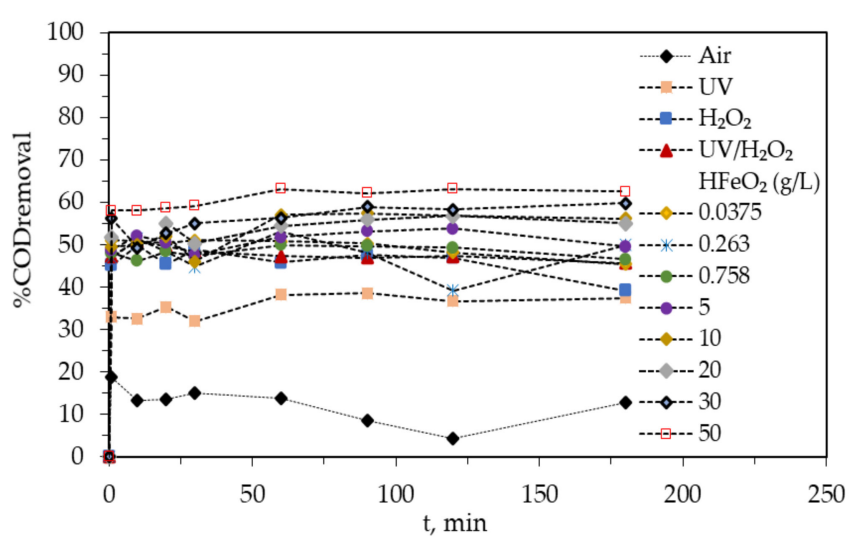

(a)

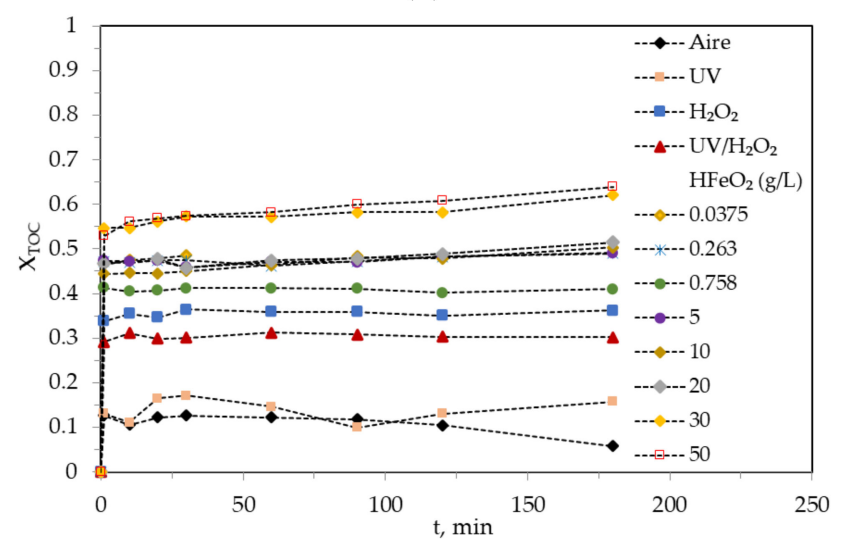

(c)

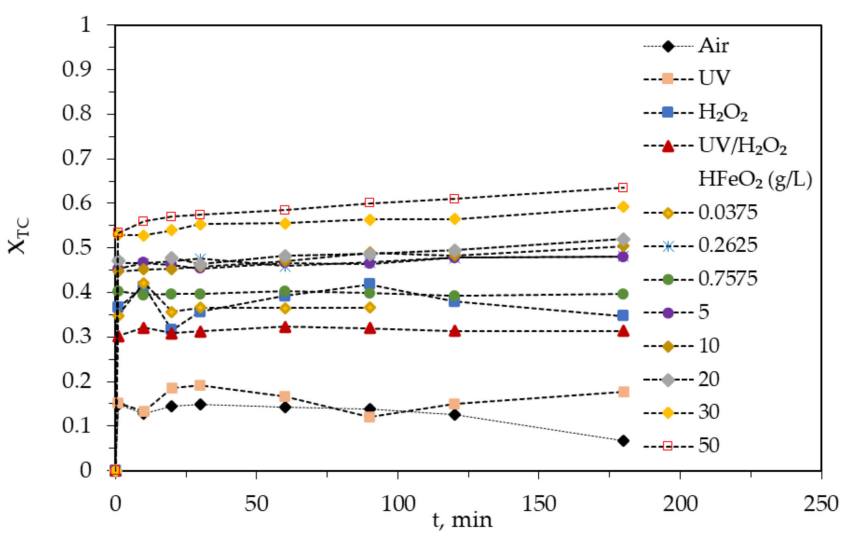

(b)

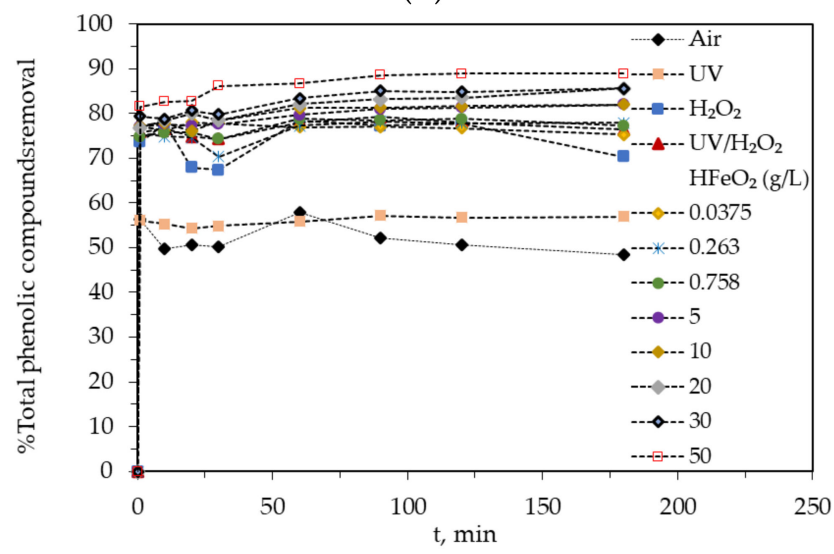

(d)

Figure 2. Variation of organic matter degradation of OMW throughout the experiment time for different chemical oxidation systems: air, $\mathrm{UV}, \mathrm{H}_{2} \mathrm{O}_{2}, \mathrm{UV} / \mathrm{H}_{2} \mathrm{O}_{2}$, and $\mathrm{UV} /$ catalyst $/ \mathrm{H}_{2} \mathrm{O}_{2}$ with different catalysts doses. (a) Removal percentages of $\mathrm{COD},(\mathbf{b})$ conversion degree of total carbon, (c) conversion degree of total organic carbon, (d) removal percentages of total phenolic carbon. Common operating conditions: $\mathrm{COD}_{\text {initial }}=16586 \mathrm{mg} \mathrm{O} / \mathrm{L}, \mathrm{H}_{2} \mathrm{O}_{2}=35.3 \mathrm{~g} / \mathrm{L}, \mathrm{T}=20^{\circ} \mathrm{C}$, agitation speed $=700 \mathrm{rpm}$, and $\mathrm{pH}=3$. 
The OMW photodegradation profiles by heterogeneous photo-Fenton reaction using $\mathrm{HFeO}_{2}$ as a catalyst are similar to those obtained by Agabo and Hodaifa [23], Hodaifa et al. [17], and Martínez-Nieto [22,32] for homogenous photo-Fenton reaction. In fact, Figure 3 shows the degradation capacity of the system $\mathrm{UV} / \mathrm{HFeO}_{2} / \mathrm{H}_{2} \mathrm{O}_{2}$, in which the degradation is increased with the reaction time.

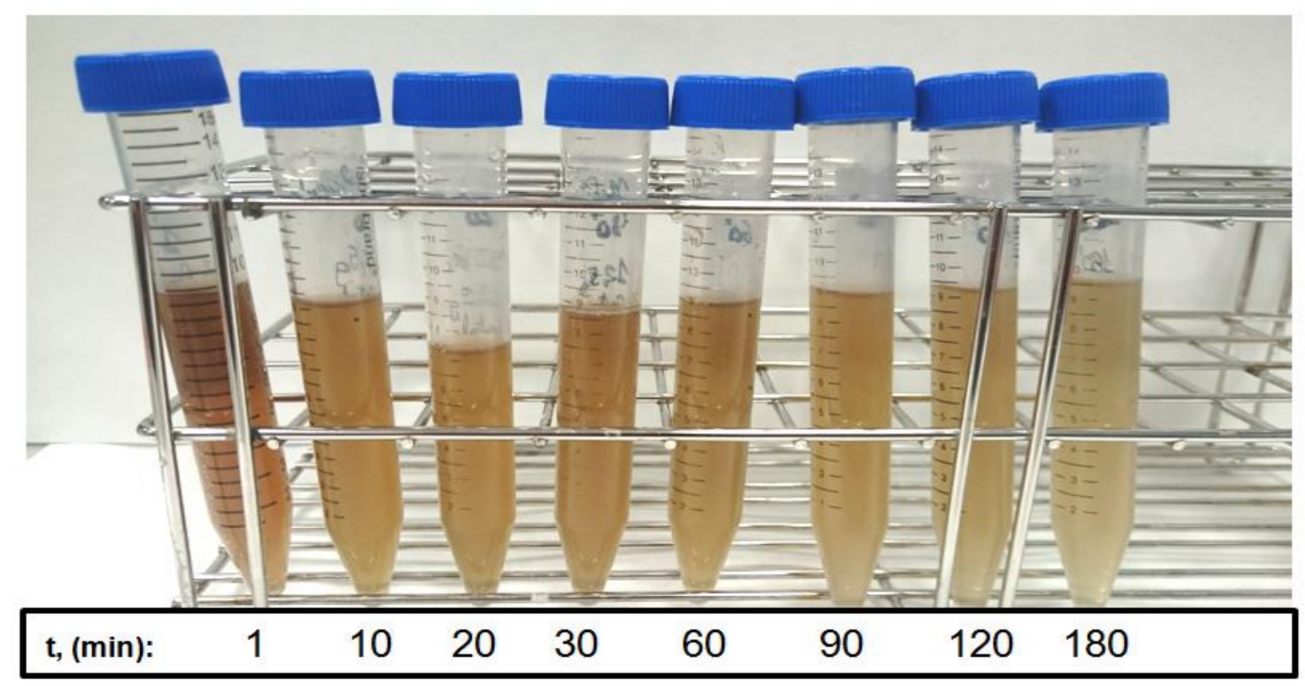

Figure 3. OMW samples after centrifugation taken at different times of photo-Fenton treatment (UV/ $\mathrm{HFeO}_{2} / \mathrm{H}_{2} \mathrm{O}_{2}$ ). Common operating conditions: $\mathrm{COD}_{\text {initial }}=16586 \mathrm{mg} \mathrm{O}_{2} / \mathrm{L}, \mathrm{H}_{2} \mathrm{O}_{2}=35.3 \mathrm{~g} / \mathrm{L}$, $\left[\mathrm{HFeO}_{2}\right]=30 \mathrm{~g} / \mathrm{L}, \mathrm{T}=20^{\circ} \mathrm{C}$, agitation speed $=700 \mathrm{rpm}$, and $\mathrm{pH}=3$.

Figure $2 \mathrm{~d}$ shows that it is possible to degrade the included phenolic compounds, \%TOC removal, of OMW with all oxidation systems evaluated; air and UV appeared to be the least powerful oxidation treatments. In contrast, the photo-Fenton system with $50 \mathrm{~g} / \mathrm{L}$ catalyst degraded about $90 \%$ of the total phenolic content in the samples. In general, when the $\mathrm{HFeO}_{2}$ concentration was increased, the \%TPCs removal was also slightly increased. However, it can be seen that even for air and UV systems, TPCs removal was equal to $52.3 \pm 3.53 \%$ and $56.7 \pm 0.542 \%$, respectively. The $\mathrm{H}_{2} \mathrm{O}_{2}$ system registered $\% \mathrm{TPCs}_{\text {removal }}=75.0 \pm 3.05 \%$, and the $\mathrm{UV} / \mathrm{H}_{2} \mathrm{O}_{2}$ system provided a slightly higher value equal to $76.8 \pm 1.73 \%$. This fact indicates the susceptibility of phenolic compounds to be oxidized, which gives them a perfect buffering capacity of oxidation of other important compounds such as lipids, proteins, vitamins, dyes, carbohydrates, and pigments of the food industry [33]. The majority of phenolic compounds (5\% of organic matter) are transferred to wastewater in olive oil production [34] and eliminated (75-80\%) in a short period of time (few minutes, Figure 2d). Evidently, this treatment is more efficient for the degradation of phenolic compounds than for COD, despite the fact that both reflect the organic matter content. This advantage in the degradation of phenolic compounds could be due to the fact that these molecules are found in simpler forms and are therefore easier to attack, while COD may involve molecules with high molecular weight such as lignin and cellulose, among others [35].

\subsection{Catalyst and Oxidant Agent Residue}

In all chemical oxidation processes, the elimination of chemical agents after treatment must be a priority in order to avoid a new problem in the wastewater target. In this sense, the residual content of both agents $\left(\mathrm{H}_{2} \mathrm{O}_{2}\right.$ and iron) was measured, as well as turbidity values. The initial iron value was $28.1 \mathrm{mg} / \mathrm{L}$, and the final residual iron value was between 2.05 and $3.40 \mathrm{mg} / \mathrm{L}$ for photo-Fenton like reactions at any concentration and $\mathrm{UV} / \mathrm{Fe}-$ catalyst $/ \mathrm{H}_{2} \mathrm{O}_{2}$ systems, removing between 87.9 and $92.7 \%$ of iron. These results are similar to those determined for other homogenous photocatalysis reactions (using catalysts such 
as $\mathrm{FeCl}_{3}, \mathrm{Fe}_{2}\left(\mathrm{SO}_{4}\right)_{3} \cdot \mathrm{H}_{2} \mathrm{O}$, and $\left.\mathrm{FeSO}_{4} \cdot 7 \mathrm{H}_{2} \mathrm{O}\right)$ after performing a catalyst separation step, normally by natural sedimentation or sedimentation-flocculation [17].

Meantime, the initial iron on OMW was $0.516 \mathrm{mg} / \mathrm{L}$, and the residual total iron determined for air, $\mathrm{H}_{2} \mathrm{O}_{2}$, photolysis, and $\mathrm{UV} / \mathrm{H}_{2} \mathrm{O}_{2}$ systems were lower than that value. This was due to the possible complex formation of iron ions with the organic matter present in OMW. For the heterogeneous photocatalysis, the concentration of iron in the final treated water was detected in the range of 2.05 to $3.20 \mathrm{mg} / \mathrm{L}$ (average value and standard deviation $=2.63 \pm 0.389 \mathrm{mg} / \mathrm{L}$ ), (Table 2). In general, the heterogeneous catalysts should avoid residual iron generation, but during the photooxidation some iron species are generated as residual iron, which can be removed by centrifugation or sedimentation because it generates flocculent aggregates that tend to sediment. This effect can be also appreciated in the turbidity values. The initial turbidity values (3453 FTU) were reduced to $67.8 \%$ and $73.0 \%$ for $\mathrm{UV}$ and $\mathrm{H}_{2} \mathrm{O}_{2}$, respectively. However, for photolysis and photo-Fenton like reactions, the turbidity removal percentages were increased to $83.7-89.1 \%$.

Table 2. Final values of parameter (turbidity, residual oxidant agent, and total iron) determined for treated water at the end of the experiments and after sample centrifugation.

\begin{tabular}{ccccc}
\hline $\begin{array}{c}\text { Oxidation } \\
\text { System }\end{array}$ & $\begin{array}{c}\mathbf{H F e O}_{2} \\
(\mathbf{g} / \mathbf{L})\end{array}$ & $\begin{array}{c}\text { Turbidity } \\
\text { (FTU) }\end{array}$ & $\begin{array}{c}\text { Residual } \\
\mathbf{H}_{\mathbf{2}} \mathbf{O}_{2} \\
(\mathbf{g} / \mathbf{L})\end{array}$ & $\begin{array}{c}\text { Residual } \\
\text { Total-Fe } \\
\text { (on OMW) } \\
\text { (mg/L) }\end{array}$ \\
\hline $\mathrm{Air}$ & - & 1469.5 & - & 0.431 \\
$\mathrm{H}_{2} \mathrm{O}_{2}$ & - & 930 & 4.58 & 0.199 \\
$\mathrm{UV}$ & - & 1111 & 1.06 & 0.368 \\
$\mathrm{UV} / \mathrm{H}_{2} \mathrm{O}_{2}$ & - & 556 & 3.80 & 0.0650 \\
& 0.04 & 562 & 5.00 & 2.93 \\
& 0.25 & 544 & 5.02 & 2.32 \\
& 0.75 & 569 & 4.99 & 2.66 \\
$\mathrm{UV} / \mathrm{H}_{2} \mathrm{O}_{2} / \mathrm{HFeO}_{2}$ & 5.00 & 437 & 4.97 & 2.05 \\
& 10.0 & 469 & 4.78 & 2.32 \\
& 20.0 & 385 & 5.09 & 2.47 \\
& 30.0 & 447 & 4.94 & 3.12 \\
& 50.0 & 376 & 5.14 & 3.20 \\
\hline
\end{tabular}

Regarding the residual $\mathrm{H}_{2} \mathrm{O}_{2}$ concentrations after the use of each oxidation system, it can be observed that no residual $\mathrm{H}_{2} \mathrm{O}_{2}$ was found after air oxidation, which is normal since no oxygen peroxide was added to the wastewater. After wastewater photolysis with artificial UV light, a concentration of $1.06 \mathrm{~g} / \mathrm{L}$ of $\mathrm{H}_{2} \mathrm{O}_{2}$ was detected (Table 2). This was due to the production of hydrogen peroxide via UV-photolysis in the presence of some catalyst such as that contained in the OMW used (Table 1). In this sense, the UV light lamp used had a nominal level of emission intensity in the range of $200-280 \mathrm{~nm}$ and a power equal to $150 \mathrm{~W}$. To confirm the hydrogen peroxide production, a control experiment was performed using tap water, $\mathrm{HFeO}_{2}$ as catalyst, and under UV lamp exposure. The results showed the generation of $0.106 \mathrm{~g} / \mathrm{L}$ of $\mathrm{H}_{2} \mathrm{O}_{2}$ after $160 \mathrm{~min}$ (Figure 4). Similar results were reported by other authors as Campos-Martin et al. [36] and Hayes et al. [37]. 


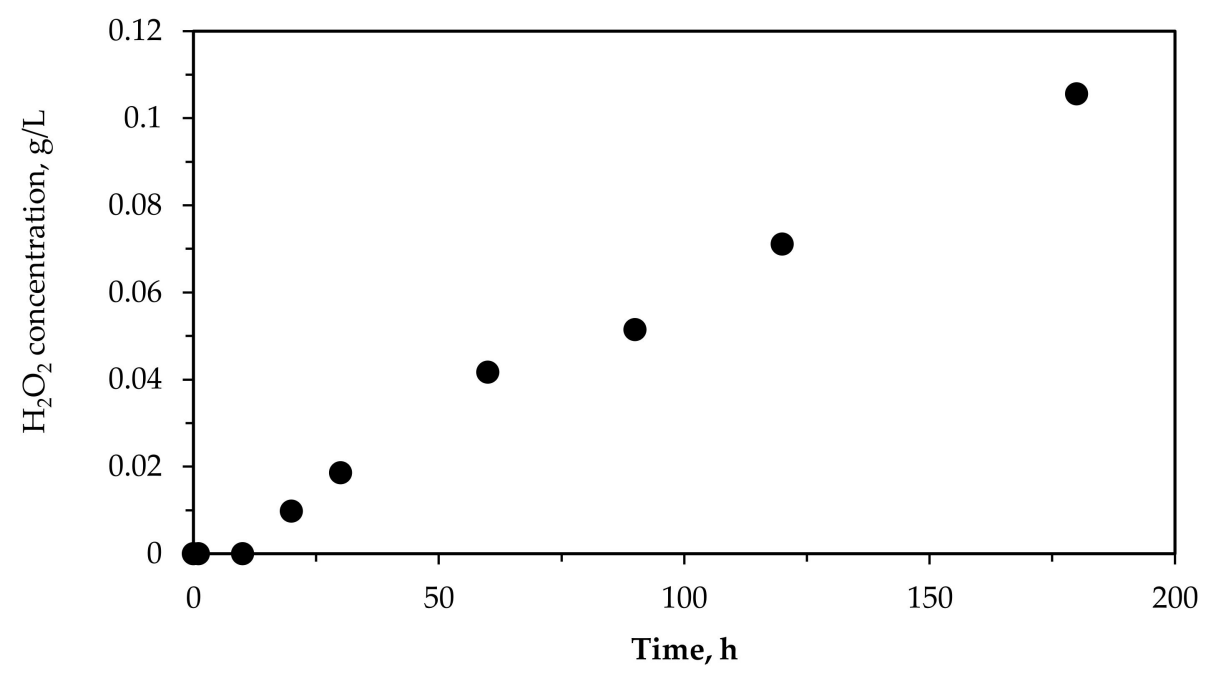

Figure 4. $\mathrm{H}_{2} \mathrm{O}_{2}$ production using tap water in presence of catalyst $\left(\mathrm{HFeO}_{2}\right)$ and UV-light generated by the lamp used in this work.

\subsection{Catalyst Reuse}

In this work, the catalyst was recovered and reused in photocatalysis up to three consecutive times to compare the efficient loss after each reuse. After each round of recovery (catalyst separation from OMW, treated, and then dried in an oven at $105^{\circ} \mathrm{C}$ ), the catalyst quantity recovered was around $90 \%(w / w)$. The separation of the catalyst was instantaneous by natural sedimentation due to its high density.

Table 3 shows the catalyst $\left(\mathrm{HFeO}_{2}\right)$ quantities recuperated after each reutilization. As can be seen in Table 3, it was possible to recover a high percentage of the catalyst used, which represents an advantage compared to homogeneous catalysis, in which the catalyst can be used only once. Recovery was possible because this catalyst can precipitate instantaneously, thus facilitating its separation from the other components in the water. In addition, it is important to indicate the lower percentage in the first recovery $(87.6 \%)$ of the commercial catalyst used, which was associated with a small percentage of fine particles that were difficult to separate from the water by gravity.

Table 3. Recovery percentage of the catalyst after use in the photo-Fenton oxidation for OMW treatment.

\begin{tabular}{cc}
\hline Reutilization Number & \% Amount Recovered After Each Use of $\mathbf{H F e O}_{\mathbf{2}}$ \\
\hline First & 87.6 \\
\hline Second & 92.9 \\
\hline Third & 91.0 \\
\hline
\end{tabular}

In the reuse experiments, a final $\mathrm{pH}$ adjustment to around the value of 7 of the treated water was carried out, which is between the levels stipulated by the legislation (Spanish Royal Decree 849/1986, pH between 5.5 and 9), and this adjustment also favored the precipitation of colloidal organic matter and iron in the form of iron hydroxide that remained in suspension after oxidation. Table 4 shows how the levels of all parameters were considerably reduced (after natural OMW sedimentation for $24 \mathrm{~h}$ and photooxidation), even after the third reuse of $\mathrm{HFeO}_{2}$. 
Table 4. Final values of main characterization parameters after natural OMW sedimentation (sedimented OMW) and photo-Fenton-like treatment in different rounds, reusing the heterogeneous $\mathrm{HFeO}_{2}$ catalyst.

\begin{tabular}{|c|c|c|c|c|c|c|}
\hline \multirow{2}{*}{ Parameter } & \multirow{2}{*}{ Crude OMW } & \multirow{2}{*}{ Sedimented OMW } & \multicolumn{3}{|c|}{ Catalyst Reuse Number } & \multirow{2}{*}{$\begin{array}{c}\text { \%Average } \\
\text { Final } \\
\text { Removal }\end{array}$} \\
\hline & & & 1 & 2 & 3 & \\
\hline $\mathrm{COD}\left(\mathrm{mg} \mathrm{O}_{2} / \mathrm{L}\right)$ & 16,586 & 14,098 & 4913 & 4965 & 4666 & 65.6 \\
\hline Total carbon $(\mathrm{mg} / \mathrm{L})$ & 4431.2 & 3776.5 & 1578 & 1333 & 1305 & 62.7 \\
\hline TPCs (mg/L) & 288.0 & 279.4 & 30.4 & 16.4 & 20.1 & 92.0 \\
\hline Turbidity (FTU) & 3453 & 3108 & 27.9 & 4.7 & 67.5 & 98.9 \\
\hline Total iron $(\mathrm{mg} / \mathrm{L})$ & 28.1 & 26.9 & 1.9 & 2.0 & 1.6 & 93.2 \\
\hline
\end{tabular}

In general, no variation of the values of the removal percentage of the parameters COD $\left(70.8 \pm 0.786 \mathrm{mg} \mathrm{O}_{2} / \mathrm{L}, \mathrm{TC}(68.3 \pm 0.738 \mathrm{mg} / \mathrm{L})\right.$, total phenolic compounds $(92.3 \pm 0.0357 \mathrm{mg} / \mathrm{L})$, turbidity $(99.0 \pm 0.156 \mathrm{FTU})$, and total iron $(93.5 \pm 0.00102 \mathrm{mg} / \mathrm{L})$ were determined after the three reutilizations. However, the value of two parameters, COD and total phenolic compounds, did not comply with the national recommendation for wastewater discharge into sewage systems $(C O D=500 \mathrm{mg} / \mathrm{L}$ and $1 \mathrm{mg} / \mathrm{L})$ according to the Spanish Royal Decree 849/1986 for "olive oil production industry". However, the limit for iron values $(10 \mathrm{mg} / \mathrm{L})$ was reached after the third round of recovery. As the competency of regulation discharge belongs to Local Authorities in Spain, the government of Seville established other limits, i.e., total phenolic compounds, $3 \mathrm{mg} / \mathrm{L}$, and iron, $10 \mathrm{mg} / \mathrm{L}$, in its Regulating Ordinance published on the official Gazette No. 117. Therefore, the reuse of this catalyst can make this process more economical and efficient. In this sense, it is interesting to indicate that for a real process for OMW treatment, the process does not contain only the photooxidation step, which means that the addition to other separation units before and after photooxidation makes it possible to achieve the legislation limits established by the authorities.

\section{Materials and Methods}

\subsection{Chemicals}

For the photo-Fenton oxidation, the catalyst used in this study was $\mathrm{HFeO}_{2}$ from Sigma-Aldrich (Madrid, Spain).

Hydrogen peroxide solution ( $30 \% \mathrm{w} / \mathrm{v})$ in stable form, Manganese IV oxide, and potassium dichromate, $99.5 \%$, were purchased from Fisher Scientific (Barcelona, Spain). Hydrochloric acid 37\% was purchased from Acro organics (Spain). Titanium (IV) oxysulphatesulphuric acid solution $27-31 \% \mathrm{H}_{2} \mathrm{SO}_{4}$ was supplied by Fluka Analytical (Barcelona, Spain).

\subsection{Methodology}

The oxidation reaction was performed in a photo-reactor with $1 \mathrm{~L}$ total capacity. In all experiments, $500 \mathrm{~mL}$ of wastewater was used, and $\mathrm{HFeO}_{2}$ in solid state with a size particle of 30-50 mesh was used as a catalyst. Two sets of experiments were developed: the first with different catalyst concentrations $(0.04 ; 0.25 ; 0.75 ; 5.00 ; 10.0 ; 20.0 ; 30.0 ; 50.0 \mathrm{~g} / \mathrm{L})$, and the second with reusable catalysts at $50 \mathrm{~g} / \mathrm{L}$ of concentration. For the reusing experiments, after any round of treatment, natural sedimentation was developed, separating the liquid phase from the catalyst. After that, the catalyst was washed with distilled water and dried in an oven at $105^{\circ} \mathrm{C}$.

Four control experiments were also carried out as follows:

- Oxidation with only air.

- Oxidation with UV alone (photolysis).

- Oxidation with only $\mathrm{H}_{2} \mathrm{O}_{2}$.

- Oxidation with the system $\mathrm{UV} / \mathrm{H}_{2} \mathrm{O}_{2}$.

In all experiments, the $\mathrm{pH}$ value was adjusted to 3.0 by $1 \mathrm{M} \mathrm{HCl}$. Subsequently, in the experiments including $\mathrm{H}_{2} \mathrm{O}_{2}$, a solution of $\mathrm{H}_{2} \mathrm{O}_{2}$ was diluted to reach $7.5 \%(w / v)$ of concentration as the optimal concentration. The initial hydrogen peroxide amount necessary for the complete degradation of the organic matter (COD) of OMW was calculated 
according to the reaction stoichiometry [17]. Finally, an immersion ultraviolet lamp was switched on. The UV lamp in the photo-reactor was covered by a quartz immersion tube and a quartz cooling jacket where the cooled water was pumped by a portable chiller (Mod. PolyScience, Niles, IL, USA).

A magnetic stirrer inside the photo-reactor to increase the degree of mixing of catalyst and OMW was used, allowing greater access to the UV light. The UV lamp used was an immersion lamp, model TQ 150 (standard), No 5600 1725, brand HNG Germany G4. The dimensions of the UV lamp were total immersion $384 \mathrm{~mm}$, luminous part $303 \mathrm{~mm}$, emission center at $44 \mathrm{~mm}$, and power of $150 \mathrm{~W}$. The power of the UV lamp per surface unit was $10,000 \mathrm{~W} / \mathrm{m}^{2}$, higher than the maximum power of the sun for an average day $\left(146 \mathrm{~W} / \mathrm{m}^{2}\right)$, [38]. Inner photo-reactor temperature was controlled through a quartz-cooling jacket located around the UV lamp.

The common operating conditions were $\mathrm{pH}=3$, temperature $=20^{\circ} \mathrm{C}$, and stirring rate $=700 \mathrm{rpm}$. The temperature and $\mathrm{pH}$ conditions were selected according to our previous work [17]. The stirring rate used was the minimum rate, which kept all the catalyst in suspension, so that it would be available at any point in the photoreactor to approximate to the degree of perfect mixing in the reactor. We started from $60 \mathrm{rpm}$ up to the best stirring rate for this heterogeneous catalyst. These experiments were realized with catalyst and tap water. For the photoreaction monitoring, $40 \mathrm{~mL}$ of effluent were sampled at 3, 10, 20, 30, 60, 120 , and $180 \mathrm{~min}$. In this sense, after each sample was taken, the catalyst was separated by natural sedimentation, as the separation was instantaneous.

\subsection{Analytical Methods}

Real OMWs were characterized by measuring the following parameters: $\mathrm{pH}$ value, electric conductivity, turbidity, moisture and volatile materials, total solids, organic matter, ashes, chemical oxygen demand (COD), total carbon (TC), total organic carbon (TOC), inorganic carbon (IC), total nitrogen (TN), total phenolic compounds (TPCs), total iron, chloride, sulphates, sodium, ammonium, potassium, calcium, zinc, magnesium, manganese, and iron.

The value of $\mathrm{pH}$ was measured using a CRISON pH meter, mod. LPG 22 (Barcelona, Spain).

Electric conductivity was determined directly by a CRISON conductivity meter, GLP31 model.

Turbidity was measured by a Turbidimeter Hanna, mod. HI93703 (Barcelona, Spain).

The total solids and moisture and volatile materials were determined according to the weight loss of the sample after being placed in an oven, type Memmert mod. UF110 Memmert $\mathrm{GmbH}+\mathrm{Co} \mathrm{KG}$ (Schwabach, Germany) at $105 \pm 1^{\circ} \mathrm{C}$.

Ashes were determined by using an oven, type CARBOLITE mod. ELF14 of Gero Ovens (Chelmsford, United Kingdom) at $575 \pm 5^{\circ} \mathrm{C}$.

The percentage of organic matter was calculated as the percentage of total solid minus the percentage of ashes.

Chemical oxygen demand (COD) was measured by photo-metric determination, by using a UV-Visible Spectrophotometer, type Evolution 201 (Thermo Scientific) at $620 \mathrm{~nm}$, of the concentration of chromium (III) after $2 \mathrm{~h}$ of oxidation with potassium dichromate/sulphuric acid/silver sulphate at $148{ }^{\circ} \mathrm{C}$ [39].

Total carbon (TC) represents all the carbon contained in a sample, which includes organic and inorganic carbon (TC = TOC + IC); total organic carbon (TOC) is the organic carbon that is converted into carbon dioxide after oxidation (TOC = TC $-\mathrm{IC}$ ), inorganic carbon (IC) is the inorganic carbon in a sample that, after acidification, turns into carbon dioxide. IC includes all carbonates, bicarbonate, and dissolved carbon dioxide (IC $=\mathrm{TC}-\mathrm{TOC}$ ), and total nitrogen (TN) is all nitrogen in the sample, which includes organic and inorganic nitrogen. Total Carbon and Nitrogen were determined using an analyzer provided by Skalar Analytical B.V Company, mod. Formacs ${ }^{\mathrm{HT}}$ and Formacs ${ }^{\mathrm{TN}}$ (Breda, The Netherlands).

Total phenolic compounds (TPCs) were determined by making them react with a derivative thiazole, producing a purple azo dye, which was measured photometrically at 
$475 \mathrm{~nm}$ by using a UV-Visible spectrophotometer, type Evolution 201 of Thermo Scientific (Barcelona, Spain) [40,41].

Total iron ions were determined by reduction of all iron ions to iron ion (II) in a thioglycolate medium with a derivative of triazine. This reaction results in a reddish-purple complex that was determined photometrically by the using UV-Visible spectrophotometer, type Evolution 201 (Thermo Scientific) at $565 \mathrm{~nm}[40,41]$.

Sulfates and chloride were determined photometrically at $420 \mathrm{~nm}$ and $450 \mathrm{~nm}$ by using the UV-Visible spectrophotometer, type Evolution 201 (Thermo Scientific), respectively [40,41].

The ions of $\mathrm{Na}, \mathrm{NH}_{4}, \mathrm{~K}, \mathrm{Ca}, \mathrm{Cu}, \mathrm{Zn}, \mathrm{Mg}, \mathrm{Mn}$ were determined by using selective electrodes supplied by Crison, mod. GLP22 (Barcelona, Spain) and Hatch mod. HQ40d (Madrid, Spain).

\subsection{Calculations and Kinetics}

Removal percentages for each parameter were calculated as follows:

$$
\% \text { Removal of the parameter }=\frac{\left(\text { Parameter }_{\mathrm{o}}-\text { Parameter }_{\mathrm{i}}\right)}{\text { Parameter }_{\mathrm{o}}}
$$

where 'Parameter ${ }_{\mathrm{o}}$ ' is the value of the parameter at the time equal to 0 (at the beginning of the experiment), and 'Parameter ${ }_{i}$ ' corresponds to the value of the parameter at any time during the experiment.

For the kinetic study of organic matter degradation by photo-Fenton reaction, the TOC parameter was selected due to its high selectivity and sensibility to any change in organic matter [42]. In this sense, taking into account that the reaction was developed in a batch stirred tank reactor and considering a constant density of the mixture, TOC conversion could be calculated as follows:

$$
\mathrm{X}_{\mathrm{TOC}}=\frac{\left(\mathrm{TOC}_{\mathrm{o}}-\mathrm{TOC}_{\mathrm{i}}\right)}{\mathrm{TOC}_{\mathrm{o}}}
$$

where ' $\mathrm{TOC}_{0}$ ' is the TOC value at $\mathrm{t}=0 \mathrm{~h}$ (at the beginning of the experiment), ' $\mathrm{TOC}_{\mathrm{i}}$ ' is the TOC value at any time during the photoreaction, and ' $\mathrm{X}_{\mathrm{TOC}}$ ' is the degree of conversion of the organic matter represented on TOC base.

The mathematical calculation and graphics were made by using the Excel program.

\section{Conclusions}

For the degradation of OMW, different oxidation systems (air injection, artificial UV light, hydrogen peroxide addition, $\mathrm{UV} / \mathrm{H}_{2} \mathrm{O}_{2}$, and $\mathrm{HFeO}_{2} / \mathrm{UV} / \mathrm{H}_{2} \mathrm{O}_{2}$ ) were used. In the case of air injection, the following removal percentages were achieved: $\% \mathrm{COD}=35.5 \%$; $\% \mathrm{TOC}=15.0 \% ; \% \mathrm{TPC}=57.0 \%$, and $\%$ turbidity $=72.5 \%$. Artificial UV light degraded OMW but to a lesser extent than hydrogen peroxide. All oxidation systems used in this work recorded removal percentages above $50 \%$ for total phenolic compounds, except for the air injection system, and the highest percentage (88.8\%) was recorded for the $\mathrm{UV} / \mathrm{H}_{2} \mathrm{O}_{2} / \mathrm{HFeO}_{2}$ system when $50 \mathrm{~g} / \mathrm{L}$ of $\mathrm{HFeO}_{2}$ was used as catalyst. This fact makes it possible to extrapolate this treatment system to other industrial wastewaters. The use of heterogeneous oxidation systems allows treatment without catalyst contamination and reduces overall treatment costs. Finally, it can be indicated that the oxidation system by heterogeneous catalysis, studied in this work, could be complemented with other upstream or downstream separation units to achieve a higher percentage of degradation in order to comply with the legal standards established for the quality of treated water for use in irrigation or in the process itself.

\section{Patents}

Hodaifa, G.; Agabo-García, C. Method for wastewater treatment based on photooxidation by ultraviolet light. Patent ES-2673673-B1, 2019. 
Author Contributions: Conceptualization, G.H.; methodology, G.H.; software, G.H. and C.A.-G.; validation, G.H., N.C., and C.A.-G.; formal analysis, G.H. and N.C.; investigation, N.C. and G.H.; resources, G.H.; data curation, G.H., N.C., and C.A.-G.; writing-original draft preparation, C.A.-G.; N.C and G.H.; writing-review and editing, G.H.; visualization, G.H.; supervision, G.H.; project administration, G.H.; funding acquisition, G.H. All authors have read and agreed to the published version of the manuscript.

Funding: This research was funded by Junta of Andalusia and Ministry of Economy and Competitiveness (Spain) "Project: Application of advanced oxidation technologies for treating of washing wastewaters of olive oil and olives, grant number AGR-7092".

Data Availability Statement: The data presented in this study are available on request from the corresponding author.

Acknowledgments: The Junta of Andalusia and Ministry of Economy and Competitiveness (Spain) are acknowledged for financial support through Project Ref.: AGR-7092 “Application of advanced oxidation technologies for treating of washing wastewaters of olive oil and olives". Authors also thank the University of Pablo de Olavide for its "Financing of the Bridge Projects" charged to the Strengthening Plan for R+D+i funded by the Ministry of Economy and Knowledge of the Junta of Andalucía, Ref.: CTM2016-78950-C2-1-R.

Conflicts of Interest: The authors declare no conflict of interest.

\section{References}

1. Azbar, N.; Bayram, A.; Filibeli, A.; Muezzinoglu, A.; Sengul, F.; Ozer, A. A Review of Waste Management Options in Olive Oil Production. Crit. Rev. Environ. Sci. Technol. 2004, 34, 209-247. [CrossRef]

2. Niaounakis, M.; Halvadakis, C.P. Olive-Mill Waste Management-Literature Review and Patent Survey; Elsevier: Amsterdam, The Netherlands, 2004.

3. Niaounakis, M.; Halvadakis, C.P. Olive Processing Waste Management, 2nd ed.; Elsevier: Amsterdam, The Netherlands, 2006; Volume 5, pp. 23-64.

4. Hodaifa, G.; Sanchez, S.; Martínez, M.E.; Órpez, R. Biomass production of Scenedesmus obliquus from mixtures of urban and olive-oil mill wastewaters used as culture medium. Appl. Energy 2013, 104, 345-352. [CrossRef]

5. Hodaifa, G.; Martínez, M.E.; Sánchez, S. Use of industrial wastewater from olive-oil extraction for biomass production of Scenedesmus obliquus. Bioresour. Technol. 2008, 99, 1111-1117. [CrossRef] [PubMed]

6. Hodaifa, G.; Páez, A.; Agabo-García, C.; Ramos, J.; Gutiérrez, J.; Rosal, A. Flocculation on the Treatment of Olive Oil Mill Wastewater: Pretreatment. Int. J. Chem. Mol. Nuclear Mater. Metallur. Eng. 2015, 9, 645-650. [CrossRef]

7. Bouknana, D.; Hammouti, B.; Salghi, R.; Jodeh, S.; Zarrouk, A.; Warad, I.; Aouniti, A.; Sbaa, M. Physicochemical characterization of olive oil mill wastewaters in the eastern region of Morocco. J. Mater. Environ. Sci. 2014, 5, 1039-1058.

8. Vasileios, I.; Vaiopoulou, D.E.; Aivasidis, A. Fundamentals and applications of anaerobic digestion for sustainable treatment of food industry wastewater. In Utilization of By-Products and Treatment of Waste in the Food Industry; Oreopoulou, V., Russ, W., Eds.; Springer: Boston, MA, USA, 2007; pp. 73-98.

9. Roig, A.; Cayuela, M.L.; Sánchez-Monedero, M.A. An overview on olive mill wastes and their valorisation methods. Waste Manag. 2006, 26, 960-969. [CrossRef] [PubMed]

10. Hodaifa, G.; Agabo-García, C.; Moya, A.; Pacheco, R.; Mateo, S. Treatment of Olive Oil Mill Wastewater by UV-Light and $\mathrm{UV} / \mathrm{H}_{2} \mathrm{O}_{2}$ System. Int. J. Green Technol. 2015, 1, 46-53. [CrossRef]

11. Borja, R.; Raposo, F.; Rincón, B. Treatment technologies of liquid and solid wastes from two-phase olive oil mills. Grasas y Aceites 2006, 57, 32-46. [CrossRef]

12. Mantzavinos, D.; Kalogerakis, N. Treatment of olive mill effluents. Environ. Int. 2005, 31, 289-295. [CrossRef]

13. Paraskeva, P.; Diamadopoulos, E. Technologies for olive mill wastewater (OMW) treatment: A review. J. Chem. Technol. Biotechnol. 2006, 81, 1475-1485. [CrossRef]

14. Tsagaraki, E.; Lazarides, H.N.; Petrotos, K.B. Olive Mill Wastewater Treatment. In Utilization of By-Products and Treatment of Waste in the Food Industry; Metzler, J.B., Ed.; Springer: Berlin/Heidelberg, Germany, 2006; pp. 133-157.

15. Khoufi, S.; Aloui, F.; Sayadi, S. Treatment of olive oil mill wastewater by combined process electro-Fenton reaction and anaerobic digestion. Water Res. 2006, 40, 2007-2016. [CrossRef]

16. Cañizares, P.; Lobato, J.; Paz, R.; Rodrigo, M.A.; Saez, C. Advanced oxidation processes for the treatment of olive-oil mills wastewater. Chemosphere 2007, 67, 832-838. [CrossRef]

17. Hodaifa, G.; García, C.A.; Borja, R. Study of Catalysts' Influence on Photocatalysis/Photodegradation of Olive Oil Mill Wastewater. Determination of the Optimum Working Conditions. Catalyst 2020, 10, 554. [CrossRef]

18. Hodaifa, G.; Gallardo, P.A.R.; García, C.A.; Kowalska, M.; Seyedsalehi, M. Chemical oxidation methods for treatment of real industrial olive oil mill wastewater. J. Taiwan Inst. Chem. Eng. 2019, 97, 247-254. [CrossRef] 
19. Benitez, F.J.; Beltran-Heredia, J.; Acero, J.L.; Pinilla, M.L. Simultaneous photodegradation and ozonation plus UV radiation of phenolic acids-major pollutants in agro-industrial wastewaters. J. Chem. Technol. Biotechnol. 1997, 70, 253-260. [CrossRef]

20. Iboukhoulef, H.; Douani, R.; Amrane, A.; Chaouchi, A.; Elias, A. Heterogeneous Fenton like degradation of olive Mill wastewater using ozone in the presence of $\mathrm{BiFeO}_{3}$ photocatalyst. J. Photochem. Photobiol. A Chem. 2019, 383, 112012. [CrossRef]

21. Pera-Titus, M.; García-Molina, V.; Baños, M.A.; Giménez, J.; Esplugas, S. Degradation of chlorophenols by means of advanced oxidation processes: A general review. Appl. Catal. B Environ. 2004, 47, 219-256. [CrossRef]

22. Nieto, L.M.; Hodaifa, G.; Rodríguez, S.; Giménez, J.A.; Ochando, J. Degradation of organic matter in olive-oil mill wastewater through homogeneous Fenton-like reaction. Chem. Eng. J. 2011, 173, 503-510. [CrossRef]

23. García, C.A.; Hodaifa, G. Real olive oil mill wastewater treatment by photo-Fenton system using artificial ultraviolet light lamps J. Clean. Prod. 2017, 162, 743-753. [CrossRef]

24. Alver, A.; Baştürk, E.; Kılıç, A.; Karataş, M. Use of advance oxidation process to improve the biodegradability of olive oil mill effluents. Process. Saf. Environ. Prot. 2015, 98, 319-324. [CrossRef]

25. Michael, I.; Panagi, A.; Ioannou, L.; Frontistis, Z.; Fatta-Kassinos, D. Utilizing solar energy for the purification of olive mill wastewater using a pilot-scale photocatalytic reactor after coagulation-flocculation. Water Res. 2014, 60, 28-40. [CrossRef]

26. Martínez, F.; Calleja, G.; Melero, J.; Molina, R. Heterogeneous photo-Fenton degradation of phenolic aqueous solutions over iron-containing SBA-15 catalyst. Appl. Catal. B Environ. 2005, 60, 181-190. [CrossRef]

27. Li, Y.; Jiang, J.; Fang, Y.; Cao, Z.; Chen, D.; Li, N.-J.; Xu, Q.-F.; Lu, J.-M. TiO 2 Nanoparticles Anchored onto the Metal-Organic Framework NH2-MIL-88B(Fe) as an Adsorptive Photocatalyst with Enhanced Fenton-like Degradation of Organic Pollutants under Visible Light Irradiation. ACS Sustain. Chem. Eng. 2018, 6, 16186-16197. [CrossRef]

28. Cong, Y.; Li, Z.; Zhang, Y.; Wang, Q.; Xu, Q. Synthesis of $\alpha-\mathrm{Fe}_{2} \mathrm{O}_{3} / \mathrm{TiO}_{2}$ nanotube arrays for photoelectro-Fenton degradation of phenol. Chem. Eng. J. 2012, 191, 356-363. [CrossRef]

29. Niu, L.; Wei, T.; Li, Q.; Zhang, G.; Xian, G.; Long, Z.; Ren, Z. Ce-based catalysts used in advanced oxidation processes for organic wastewater treatment: A review. J. Environ. Sci. 2020, 96, 109-116. [CrossRef]

30. Giannakis, S.; Lin, K.-Y.A.; Ghanbari, F. A review of the recent advances on the treatment of industrial wastewaters by Sulfate Radical-based Advanced Oxidation Processes (SR-AOPs). Chem. Eng. J. 2021, 406, 127083. [CrossRef]

31. Luo, H.; Zeng, Y.; He, D.; Pan, X. Application of iron-based materials in heterogeneous advanced oxidation processes for wastewater treatment: A review. Chem. Eng. J. 2021, 407, 127191. [CrossRef]

32. Nieto, L.M.; Hodaifa, G.; Vives, S.R.; Casares, J.A.G.; Driss, S.B.; Grueso, R. Treatment of olive-mill wastewater from a two-phase process by chemical oxidation on an industrial scale. Water Sci. Technol. 2009, 59, 2017-2027. [CrossRef]

33. Casadey, R.; Challier, C.; Altamirano, M.; Spesia, M.B.; Criado, S. Antioxidant and antimicrobial properties of tyrosol and derivative-compounds in the presence of vitamin B2. Assays of synergistic antioxidant effect with commercial food additives. Food Chem. 2021, 335, 127576. [CrossRef]

34. Sánchez-Arévalo, C.M.; Jimeno-Jiménez, Á.; Carbonell-Alcaina, C.; Vincent-Vela, M.C.; Álvarez-Blanco, S. Effect of the operating conditions on a nanofiltration process to separate low-molecular-weight phenolic compounds from the sugars present in olive mill wastewaters. Process. Saf. Environ. Prot. 2021, 148, 428-436. [CrossRef]

35. Dermeche, S.; Nadour, M.; Larroche, C.; Moulti-Mati, F.; Michaud, P. Olive mill wastes: Biochemical characterizations and valorization strategies. Process. Biochem. 2013, 48, 1532-1552. [CrossRef]

36. Campos-Martin, J.M.; Blanco-Brieva, G.; Fierro, J.L.G. Hydrogen Peroxide Synthesis: An Outlook beyond the Anthraquinone Process. Angew. Chem. Int. Ed. 2006, 45, 6962-6984. [CrossRef] [PubMed]

37. Hayes, J.; Schubert, D.; Amonette, J.; Nachimuthu, P.; Disselkamp, R. Ultraviolet stimulation of hydrogen peroxide production using aminoindazole, diaminopyridine, and phenylenediamine solid polymer complexes of Zn(II). J. Photochem. Photobiol. A Chem. 2008, 197, 245-252. [CrossRef]

38. Patil, S.; Kumar, N. Sun light transmission through silica optical fibers for lighting: An experimental study. Mater. Today Proc. 2018, 5, 22943-22949. [CrossRef]

39. DIN 38409-41. German Standard Methods for Examination of Water, Waste Water and Sludge; Summary Action and Material Characteristic Parameters (Group H); Determination of the Chemical Oxygen Demand (COD) in the Range over $15 \mathrm{mg} / \mathrm{L}$ (H41); German Institute for Standardisation (Deutsches Institut für Normung): Berlin, Germany, 1980.

40. ISO 8466-1. Water Quality-Calibration and Evaluation of Analytical Methods and Estimation of Performance Characteristics-Part 1: Statistical Evaluation of the Linear Calibration Function; International Organization for Standardization: Genève, Switzerland, 1990.

41. DIN 38402 A51. German Standard Methods for the Examination of Water, Waste Water and Sludge; General Information (Group A); Calibration of Analytical Methods, Evaluation of Analytical Results and Linear Calibration Functions Used to Determine the Performance Characteristics of Analytical Methods (A 51); German Institute for Standardisation (Deutsches Institut für Normung): Berlin, Germany, 1986.

42. Dubber, D.; Gray, N.F. Replacement of chemical oxygen demand (COD) with total organic carbon (TOC) for monitoring wastewater treatment performance to minimize disposal of toxic analytical waste. J. Environ. Sci. Health A Tox. Hazard. Subst. Environ. Eng. 2010, 45, 1595-1600. [CrossRef] 